\title{
THE IMPACT OF GILTI AND FDII ON THE INVESTMENT LOCATION CHOICE OF U.S. MULTINATIONALS
}

\author{
Kartikeya Singh* \& Aparna Mathur**
}

\begin{abstract}
This article analyzes the impact of two new international tax provisions, GILTI and FDII, passed under the Tax Cuts and Jobs Act, on U.S. multinational corporations' location of new capital. We analyze whether these rules help retain internationally mobile rents within the U.S. tax base and the associated economic activity within the United States. Our analysis suggests that for a wide range of investment profiles (characterized in terms of scale and expected abovenormal returns) for intangible capital, a U.S. MNC can do better by locating a new investment in the United States.
\end{abstract}

* Principal, PricewaterhouseCoopers. Email. kartikeya.singh@us.pwc.com.

** Resident Scholar, Economic Policy Studies, American Enterprise Institute. Email: amathur@aei.org. The authors thank Marco Fiaccadori, Joe Murphy and Alan Viard for helpful comments and discussion on the paper, and Cody Kallen for research support. The views expressed in this article are solely the authors' and do not reflect the views of any other person or institution. 


\section{TABLE OF CONTENT}

$\begin{array}{ll}\text { I. INTRODUCTION } & 201\end{array}$

II. TAXATION OF INCOME FROM CAPITAL 202

III. TAXING MOBILE INCOME VIA GILTI AND FDII 206

$\begin{array}{lll}\text { A. GILTI } & 206\end{array}$

$\begin{array}{ll}\text { B. FDII } & 207\end{array}$

C. Policy Intent of GILTI and FDII 208

D. Impact of BEPS 209

IV. FIRM'S LOCATION CHOICE FOR NEW INVESTMENTS WITH GILTI AND FDII 211
A. The Imputed Return in the GILTI and FDII Rules
212
B. Intangible Capital
214
C. Tangible Capital
219

V. CONCLUSION 


\section{INTRODUCTION}

In this article, we focus on two new provisions addressing the taxation of income from mobile capital, which were passed as part of Public Law 115-97 (popularly known as the Tax Cuts and Jobs Act or TCJA) in December 2017. The provision on "global intangible low taxed income" (GILTI), which is set forth in new section 951A, is intended to make mobile capital, and the taxable income attributable to such capital, less sensitive to tax rate differentials between the United States and other jurisdictions vying for such capital. ${ }^{1}$ To achieve that goal, the provision taxes U.S. taxpayers" "mobile income" reported outside the United States when the foreign tax rate on the income falls below a minimum threshold.

While the GILTI provision is intended as the proverbial stick, the provision known by its (less catchy) acronym "FDII" is the accompanying carrot. The provision on FDII — which stands for "foreign derived intangible income," set forth in new Section 250, is intended to motivate both U.S. and foreign multinationals to locate within the United States the mobile income generated from the supply of goods, services, or intangible property that is ultimately used or consumed outside the United States. ${ }^{2}$

The reactions of foreign governments and commentators to the international tax provisions of the TCJA suggest that these provisions (together with the lower corporate tax rate) make the United States more competitive for investment. ${ }^{3}$ Some European Union governments have signaled concern that the U.S. provisions may undermine the international system shaped by the OECD's Base Erosion and Profit Shifting (BEPS) project. ${ }^{4,5}$ Similarly, European commentary points out the U.S.'s improved attractiveness as an investment location relative to European countries, particularly high-tax-rate countries like Germany. ${ }^{6}$ In contrast, the commentary on such provisions in the United States has been mixed. In particular, some have criticized the GILTI provision as not being punitive enough to achieve the desired deterrence and the FDII provision as not providing a strong enough incentive for companies to retain mobile investments in the United States. ${ }^{7}$ Critics have also claimed that the provisions create incentives to locate new investments in tangible assets overseas. ${ }^{8}$ In particular, and at least on the surface, the design of the two provisions appears to leave open a tax arbitrage opportunity for companies

${ }^{1}$ Committee Print, Reconciliation Recommendations Pursuant to H. Con. Res. 71, S. Prt. 115-20, (December 2017), p. 370.

${ }^{2}$ Id. at 375 .

${ }^{3}$ Mindy Herzfeld, Competition or Coordination: Responses to the Tax Cuts and Jobs Act, TAX NOTES, (Jan. 16, 2018).

${ }^{4} I d$.

5 Stephanie Soong Johnston, EU Commission Mulls 'All Options' in Wake of Final U.S. Tax Bill, TAX Notes, (Jan. 1, 2018).

${ }^{6}$ Friedrich Heinemann et al., Analysis of US Corporate Tax Reform Proposals and their Effects for Europe and Germany, 18 (ZEW - Ctr. for Eur. Econ. Res., Dec. 2017).

${ }^{7}$ David Kamin et al., The Games They Will Play: An Update on the Conference Committee Tax Bill, 103 MINN L. REV. (2018), https://papers.ssrn.com/sol3/papers.cfm?abstract_id=3089423 [https://perma.cc/38WSGLDL].

${ }^{8} I d$. 
to pursue. Given this, it also appears to have left open an incentive for competing governments to offer even lower corporate income tax rates to attract investment.

In this article, we analyze the effect of the two provisions on the incentives for the location of new investment by U.S. multinational corporations (MNCs). In order to do so, we discuss the policy goal of the provisions and how the design of the provisions intends to achieve their policy goals in an environment that has been shaped by the OECD's BEPS project. ${ }^{9}$ Our analysis suggests that U.S. MNCs may have strong incentives to locate new investments in intangible capital in the United States. Further, the provisions do not necessarily significantly sway the location choice for new investments in tangible capital away from the United States.

The article is organized as follows. Section II lays out a basic framework to understand the taxation of capital income and its different components. Section III describes GILTI and FDII and identifies the underlying policy intent by reference to the framework introduced in Section II. The implications of the post-BEPS international tax system are discussed in this section as well. In particular, we highlight how non-tax "transaction costs" associated with the location of mobile capital in tax-advantaged jurisdictions have increased post-BEPS and how this can influence the cost-benefit calculus underlying firms' investment location decisions. Section IV analyzes the GILTI and FDII provisions' effects on investment location decisions of U.S. MNCs and examines the validity of the different concerns expressed about these provisions. Section V concludes.

\section{TAXATION OF INCOME FROM CAPITAL}

A business's expected return on an investment can be viewed as comprising two elements. The first is the rate of return available on comparable investments in competitive capital markets. This "normal" rate of return is the opportunity cost of the investment. For an investment to be worth undertaking, its expected cash flows, discounted at the normal rate of return, must not be negative. ${ }^{10}$ The second potential element in a firm's expected return is the return in excess of its opportunity cost. Such "above normal" returns are usually taken to represent economic rents attributable to one or more unique attributes of the firm. ${ }^{11}$

The structure of a tax determines whether it taxes only economic rents (or "above normal" returns) or whether it also taxes the normal rate of return. Because economic rents are by definition over and above the return necessary to justify the investment, a tax on them does not distort the decision to invest or the level of such investment. In a world without capital mobility, a uniform tax on economic rents across sectors and asset classes is efficient because it imposes no distortion on the overall level of investment and how such investment is allocated across sectors and asset types. However, when economic rents are mobile (i.e. are not "location-

\footnotetext{
${ }^{9} \mathrm{We}$ express no opinion on the sustainability of these provisions against possible challenge by foreign governments or multilateral organizations under various international agreements.

${ }^{10}$ When dealing with a risky investment, the opportunity cost should contain a return for risk bearing (risk premium) over and above the risk-free return necessary to induce delayed consumption.

${ }^{11}$ Again, in the case of risky investments, ex-post results above the (ex-ante) normal rate of return may simply be the realization of chance rather than rents.
} 
specific"), the location of capital is sensitive to taxes, even if the level of such capital is not. ${ }^{12}$ Such mobile rents typically stem from firm-specific attributes, such as unique intangibles that can give the firm a degree of monopoly power.

In our framework we consider a one-dollar investment that starts to generate income one period later. ${ }^{13}$ The total pre-tax amount (i.e., gross-of-depreciation return) $G R_{t}$ expected to be generated by the investment in any future period $t$ is given by Equation 1 below, where $R_{t}$ denotes the normal return, $E R_{t}$ denotes the economic rent. and $D_{t}$ represents economic depreciation.

\section{Equation 1}

$$
G R_{t}=R_{t}+E R_{t}+D_{t}
$$

Assume that the expected rates of return associated with the investment in question are constant over time with the normal rate denoted by $r$ and the rate of economic rents denoted by er. Using $K_{t}$ to denote the net capital stock from the original investment carried into the current period, the dollar amount of the normal return in any given period $t$ is $r$ times $K_{t}$. In turn, $K_{t}$ equals one in the period immediately following the period in which the investment is made. For all subsequent periods, $K_{t}$ is given by Equation $2 .{ }^{14}$

\section{Equation 2}

$$
K_{t}=1-\sum_{i=1}^{t-1} D_{i}
$$

Similarly, the dollar amount of the economic rents in period $t$ is given by er times $K_{t}$. Given the above, the total pre-tax gross return from the investment in any period $t$ is given by Equation 3.

\section{Equation 3}

$$
G R_{t}=r K_{t}+e r K_{t}+D_{t}
$$

We now consider a tax code that allows for immediate expensing of the investment at a tax rate of $\tau$ and then levies a tax at the same rate on the subsequent gross returns (gross-ofdepreciation return). ${ }^{15} \mathrm{~A}$ well-known property of a tax code that permits immediate expensing of

\footnotetext{
${ }^{12}$ See, e.g., Alan J. Auerbach et al., Taxing Corporate Income, in DIMENSIONS OF TAX DESIGN: THE MirRleEs ReVIEW, (James Mirrlees et al. eds., 2010).

${ }^{13}$ See generally Org. for Econ. Co-operation and Dev. (“OECD”), OECD Tax Policy Studies No. 16: Fundamental Reform of Corporate Income Tax, OECD (2007). For now, we do not distinguish between tangible and intangible capital. For simplicity, we assume that the investment is entirely equity financed.

14 The capital stock will converge to zero under alternative assumptions with regard to depreciation that are standard in such analyses including linear depreciation (i.e., straight line schedule) as well as a constant rate of decay (i.e., geometric schedule).

15 The present discounted value of the after-tax stream of gross returns (gross-of-depreciation return) (i.e., before subtracting out the upfront cost of the investment) is given by the expression: $\tau+\mathrm{t}=1(\mathrm{rKt}+\mathrm{erKt}+\mathrm{Dt}) 1-\tau(1+\mathrm{r}) \mathrm{t}$.
} 
capital investments is that such a tax system exempts the normal return from tax. ${ }^{16}$ The tax benefit that the firm realizes from expensing fully offsets - in present value terms - the subsequent tax the firm pays on the investment's normal rate of return and the portion of the gross income that covers the depreciation of the investment. The expected stream of the normal returns generated from an investment along with the portion of returns that pay for its depreciation when discounted at the investment's opportunity cost - i.e., normal rate of return - must, by definition, equal the original investment. ${ }^{17}$ Thus, a tax benefit on that original investment must equate (in expected terms) to the tax payments on the normal rate plus economic depreciation so long as the tax rate remains unchanged over time.

Note that the above does not imply that the government stands to collect zero tax revenues under expensing when there are no rents to tax. Even when economic rents are entirely absent, the total undiscounted tax revenues received by the government would exceed the initial tax benefit of expensing; the government would earn the normal rate of return on the initial tax benefit it offered. Under expensing, the government effectively becomes a silent partner in the investment - it defrays a share of the firm's upfront cost and receives the same share of the subsequent returns. ${ }^{18}$

When the tax code does not allow for immediate expensing, and instead only permits a deduction equal to the economic depreciation of the investment (or a proxy for such depreciation based on a tax depreciation schedule), the normal rate of return from such investments bears a tax burden. ${ }^{19,20,21}$

There are sound policy reasons to exempt the normal return from tax, in order to avoid the efficiency cost of having a distorted level of investment that is below the optimal level. With the new rules allowing for 100 percent expensing for certain qualified tangible business assets (at least through 2022) under section 168(k), as amended by 13201 of the TCJA, the normal return on new investments in those assets is exempt from tax. Other things equal, this can stimulate

The first term in the expression represents the tax gain in the first period from the immediate expensing of the investment, while the second term is the present discounted value of the stream of gross returns after tax.

${ }^{16}$ See OECD., supra note 13.

${ }^{17}$ A mathematical proof is available from the authors upon request.

${ }^{18}$ With risky returns, the loss offset rules are important. With less than full loss offset, the government falls short of being a true silent partner because it does not participate symmetrically in the upside and downside realizations of the risk. Although the change in loss offset rules are an important consideration in the context of P.L. 115-97, we ignore this change in the interest of tractability.

${ }^{19} \mathrm{~A}$ mathematical exposition of this within the framework adopted in this section is available from the authors upon request.

${ }^{20}$ If the tax depreciation schedule replicates true economic depreciation, the normal rate of return bears the full extent of the tax. A tax schedule that allows for slower depreciation than the true economic rate imposes a tax on the normal return at a rate greater than the statutory rate.

${ }^{21}$ The tax burden on the normal return means that the investment would only be undertaken if the economic rents are sufficient to ensure that the one dollar investment generates at least its opportunity cost on an after-tax basis. If the economic rents generated by an investment decline for each additional dollar of investment, the scale of investment under full expensing will be greater than under a system that only allows for deductibility of the depreciation. Under the framework adopted in this section, this would be the case when the constant rate of economic rents (er) assumed for the marginal dollar of investment is a declining function of the scale of inframarginal investment. 
investment. ${ }^{22}$ With immediate expensing already applying to investments in self-developed intangibles, such as research and development, advertising and marketing, the normal return on such investments should also be exempt from U.S. tax. ${ }^{23}$

Other things equal, the expensing rules would prevent U.S. tax from distorting the level of investments in different classes of business assets. On their own, however, the expensing rules do not address concerns related to the location of such investments. As long as the economic rents from such investments are subject to U.S. tax, differences in the rates of such tax between the U.S. and other jurisdictions can motivate firms to locate their investments overseas. While tax is only one consideration among many and some forms of capital are more mobile than others, the reality of tax competition suggests that taxes are important with regard to the investment location. ${ }^{24}$

Above-normal profits from intangibles represent the most mobile form of economic rents in an international tax context. Furthermore, the cross-border mobility of such rents can take one of two forms. One form is where the "economic activity" underlying such income - to adopt the BEPS parlance of the OECD - is located in a tax-advantaged jurisdiction along with the concomitant taxable income. ${ }^{25}$ The other type of cross-border mobility - again, adopting the OECD parlance - is of the "artificial" kind where it is only the taxable income that moves to a low-tax jurisdiction without the corresponding location of the underlying economic activity (i.e., "substance") in that jurisdiction. ${ }^{26}$ It is the mobility of the "artificial" kind that has been the focus of the BEPS project. As such, new measures and guidance specifically aimed at curtailing such separation of taxable income from the underlying economic activity that gives rise to such income in the context of intangible capital constitute a significant part of the project's output. ${ }^{27}$ As discussed by the authors previously and further below, the result of this is that there are now higher non-tax transaction costs of locating mobile capital away from jurisdictions that, absent tax considerations, would be the natural home for such capital. ${ }^{28}$ It is in this post-BEPS environment that the GILTI and FDII provisions are intended to narrow, and possibly eliminate, tax-rate arbitrage on mobile rents.

${ }^{22}$ Note that this applies to equity-financed investments in qualified assets. With debt financing - and subject to the rules of I.R.C. $§ 163(\mathrm{j})$ - the effective tax on the normal return on such assets may be negative.

${ }^{23}$ However, the earlier caveat regarding imperfect loss rules, supra note 18, may be of particular relevance here.

${ }^{24}$ Michael P. Devereux \& Rachel Griffith, Evaluating Tax Policy for Location Decisions, 10 INT’L TAX AND PUB. FIN., 107-26 (2003).

${ }^{25}$ See OECD, ACTION PLAN ON BASE EROSION AND PROFIT SHIFTING 10 (OECD Publ'g, 2013) (stating that "[n]o or low taxation is not per se a cause of concern, but it becomes so when it is associated with practices that artificially segregate taxable income from the activities that generate it."

${ }^{26}$ Id. See also OECD, ALIGNING TRANSFER PRICING OUTCOMES WITH VALUE CREATION, ACTIONS 8-10 2015 FINAL REPORTS (OECD Publ'g, 2015).

${ }^{27}$ OECD, supra note 25, at 20. In particular, among the objectives covered by Action 8 was the development of rules to ensure "that profits associated with the transfer and use of intangibles are appropriately allocated in accordance with (rather than divorced from) value creation ...."

${ }^{28}$ Kartikeya Singh \& Aparna Mathur, Economic Substance Requirements and Multinational Firm Behavior, (Am. Enter. Inst. Econ., Working Paper No. 2017-02, 2017). 


\section{COLUMBIA JOURNAL OF TAX LAW}

Before we turn to those provisions, we make two additional observations. An important distinction between expensing and depreciation is reflected in what constitutes taxable income in any given period when such taxable income is attributable to a prior investment. With immediate expensing, the taxable income $(Y)$ resulting from one dollar of investment is -1 in the period during which the investment is made. For any period $t$ after the original period of investment, the taxable income is given by Equation 4 and includes the element of the gross return that pays for the economic depreciation of the investment.

\section{Equation 4}

$$
Y_{t}=r K_{t}+e r K_{t}+D_{t}
$$

In contrast, under depreciation, the taxable income in period $t$ attributable to a one-dollar investment made in the past is given by Equation 5 .

\section{Equation 5}

$$
Y_{t}=r K_{t}+e r K_{t}
$$

As described earlier, if the ongoing depreciation (or normal return) of an investment were not taxed under an expensing regime, or if such depreciation (or normal return) were taxed at a rate lower than the rate at which the original investment was expensed, the effective tax on the normal rate of return would be negative in present value terms. The opposite is true - i.e., the normal return bears a positive tax even with expensing - when the subsequent taxation of the normal return (or depreciation) takes place at a rate higher than the original expensing.

So far, we have not differentiated between investments in intangible capital and investments in tangible capital. However, a common assumption is that economic rents are usually generated by intangible assets. Further, the economic rents attributable to intangible capital are far more mobile (at least from an income tax reporting standpoint) than any rents on tangible capital.

Finally, we note that the rules of most OECD countries allow expensing for investments in research and development and marketing aimed at generating self-developed intangibles. ${ }^{29}$ In contrast (and prior to the enactment of the TCJA), most OECD countries only allowed for a tax deduction for the depreciation of most forms of tangible capital. ${ }^{30} \mathrm{We}$ now turn to the GILTI and FDII provisions and describe their policy objectives in the context of the framework presented here.

\section{TAXING MOBILE INCOME VIA GILTI AND FDII}

\section{A. GILTI}

Section 951A of the Code lays out the rules for GILTI and requires that a U.S. corporation include in its taxable income currently the "global intangible low-taxed income" of

\footnotetext{
${ }^{29}$ Kyle Pomerleau, Capital Cost Recovery across the OECD, 402 TAX FOUNDATION FISCAL FACT (2013).

${ }^{30} \mathrm{Id}$.
} 
all its controlled foreign corporations (CFCs). ${ }^{31}$ However, section 250 provides a deduction equal to 50 percent of this income. ${ }^{32}$ With a 21 percent tax rate, and absent any foreign taxes (as well as other limitations), a U.S. corporation will be subject to a 10.5 percent tax rate on the total GILTI of its CFCs.

GILTI is calculated in the aggregate for a given U.S. corporation across all of its CFCs (in proportion to the US shareholder's equity interest in each such CFC) and excludes income already subject to U.S. tax (such as ECI and Subpart F income) (as well as certain other exempt categories of income). Roughly speaking, a CFC's income subject to U.S. tax under the GILTI provision is an estimate of its overall income from business operations less a "deemed tangible income return." 33 The deemed tangible return equals 10 percent of the CFC's tax basis in depreciable tangible business assets; that tax basis, which is determined under the section 168(g) alternative depreciation schedule, is termed "Qualified Business Asset Investment" (QBAI). ${ }^{34}$

Finally, the U.S. shareholder is allowed foreign tax credits for the shareholder's proportionate share of 80 percent of the CFC's foreign income taxes that are allocable to the GILTI portion of the CFC's income. ${ }^{35}$ The GILTI rule thereby ensures a minimum rate of tax on a U.S. shareholder's CFC. In the absence of any foreign taxes, the CFC will be subject to a U.S. tax at the rate of 10.5 percent on its deemed intangible income with all its routine return attributable to tangible property (as proxied by 10 percent of its QBAI) being shielded from any U.S. tax. With a positive foreign tax rate, the effective rate of U.S. tax relating to the GILTI provision is generally lower than 10.5 percent due to foreign tax credits.

\section{B. FDII}

While the GILTI provision seeks to deter tax planning that offshores investments aimed at generating income from foreign consumption or use of property, services or IP, the complementary FDII rules seek to provide an incentive for U.S. corporations to locate such investments and income in the United States. Under section 250, a U.S. corporation is "allowed as a deduction" 37.5 percent of that portion of its taxable income that is categorized as foreign derived intangible income. ${ }^{36}$ That results in an effective tax rate of 13.125 percent on FDII, as 62.5 percent of such income is subject to the 21 percent U.S. tax rate. ${ }^{37}$

The computation of a U.S. corporation's FDII requires steps conceptually similar to the calculation of GILTI. Starting with the U.S. corporation's gross income, its total "deduction eligible income" is derived by excluding any income that is already subject to U.S. tax (such as Subpart F income and GILTI) and certain other forms of income (e.g., dividends received from

${ }^{31}$ I.R.C. $\$ 951 \mathrm{~A}$.

${ }^{32}$ For years 2026 and later, this deduction is limited to 21.875 percent. I.R.C $\$ 250(a)(3)$.

${ }^{33}$ I.R.C. $\$ 951 \mathrm{~A}(\mathrm{~b})(1)$.

${ }^{34}$ I.R.C. $\$ 951 \mathrm{~A}(\mathrm{~b})(2)$, I.R.C. $\$ 168(\mathrm{~g})$.

${ }^{35}$ Note that the GILTI computation starts with an after-tax figure and thus make the tax rules of the CFC's country, including its capital allowance rules, relevant to the GILTI amount. The final amount subject to U.S. tax under the GILTI provision is a pre-tax (i.e., taxable income equivalent) figure by way of the I.R.C. $\S 78$ "gross ups".

${ }^{36}$ For years 2026 and later, this deduction is limited to 21.875 percent. I.R.C $\$ 250(a)(3)$.

${ }^{37}$ Absent potential limitations on foreign tax credits under I.R.C $\$ 904$ that result from expense allocation rules of I.R.C $\S 861$. 
CFCs, domestic oil and gas income, foreign branch income and financial services income) and then subtracting deductions (including taxes) properly allocable to such gross income. ${ }^{38}$

From the deduction-eligible income, a "deemed tangible income return" equal to 10 percent times the corporation's QBAI, is subtracted to determine the "deemed intangible income." ${ }^{39}$ Finally, the FDII is that portion of the deemed intangible income that is attributable to sales of products, provision of services, licenses of IP, etc. for foreign consumption or use. ${ }^{40}$

\section{Policy Intent of GILTI and FDII}

Recall from Section II the policy challenge of taxing economic rents in an open economy. While exempting the normal return from capital taxation serves the goal of an undistorted level of investment, a government is susceptible to losing investment when it seeks to tax the economic rents and a competing government offers a lower tax rate. The challenge is greater when the economic rents in question come from (or can be attributed to) mobile forms of capital such as intangible assets.

A policymaker tasked with designing international tax rules to address the challenge posed by mobile economic rents would ideally want to first identify such economic rents within a taxpayer's overall taxable income. Using our expressions for taxable income from Equation 4 and Equation 5, the portion of a company's taxable income targeted by such rules should be er times that portion of $K_{t}$ that is made up of intangible capital (under the assumption that intangible capital is mobile and tangible capital is not). However, parsing a firm's observed taxable income between normal returns and economic rents (and between tangible capital and intangible capital) in an objective manner is a significant measurement problem in practical policy design. The problem is tougher still when the reported taxable income across different jurisdictions has been computed under different capital allowances (e.g., expensing or depreciation deduction for a capital expenditure) and other tax rules.

If we view the GILTI and FDII provisions as an attempt to identify mobile rents, it is clear that their drafters made certain assumptions and compromises. They assumed that 10 percent is a reasonable proxy for the normal rate of return in nominal terms and that tangible capital generally earns no more than a normal rate of return. Assuming minimal rents to tangible capital, subtracting a 10 percent return on tangible capital from taxable income would, under a specific combination of capital allowance rules for the two classes of investment, isolate the returns to intangible capital. ${ }^{41}$ This would still leave the normal return on intangibles (as well as the portion of the return covering economic depreciation) in the mix but that is not a problem under full expensing of intangible investments. However, as we discuss below, in other situations the design of the provisions will not be able to selectively target economic rents. ${ }^{42}$

In this setup, the GILTI provision is the backstop that ensures that a certain portion of the returns to mobile capital of U.S.MNCs remain in the U.S. tax base even when such returns are reported in low-tax foreign jurisdictions (via subsidiaries located in those jurisdictions). Further,

\footnotetext{
${ }^{38}$ I.R.C $\$ 250(\mathrm{~b})$.

${ }^{39}$ I.R.C $\$ 250(\mathrm{~b})(2)(\mathrm{B})$.

${ }^{40}$ I.R.C $\$ 250(\mathrm{~b})(4)$

${ }^{41}$ Specifically, this would be the case where full and immediate expensing applies for investments in intangible property but only depreciation is allowed for investments in tangible capital.

${ }^{42}$ See Sections IV.C and IV.D.
} 


\section{MULTINATIONALS}

by serving as such a backstop, the GILTI rules can help lower the incentive and ability of foreign jurisdictions to engage in tax competition to attract investment from U.S. MNCs. ${ }^{43}$

And yet, while the rules on GILTI and FDII reduce the benefit that U.S. MNCs can expect from locating mobile capital (and the rents attributable to such capital) in low-tax jurisdictions, they do not entirely eliminate such benefit. At least on the surface, the rules appear to leave open a tax-rate arbitrage window for mobile rents (albeit, a window that is smaller than before). For U.S. MNCS, simplified like-for-like comparison of the marginal U.S. tax burden on mobile rents generated from an investment (targeted at supplying non-U.S. markets) suggests that this marginal tax can be no lower than 13.125 percent when located in the United States but can be as low as 10.5 percent when located in a low-tax foreign jurisdiction (other things equal and ignoring other tax attributes specific to each jurisdiction). Given the dividend received deduction (DRD) under the TCJA, ${ }^{44}$ this means that an incentive to offshore rent-generating mobile capital may still exist among U.S. MNCs. Jurisdictions may then continue to try and attract investments of U.S. MNCs through tax competition (e.g. IP box regimes, lower tax rates, etc.). If this is indeed the case, an opportunity would appear to have been lost from the perspective of the U.S. treasury.

\section{Impact of BEPS}

In this section, we show that while such a tax arbitrage may exist, non-tax transaction costs related to BEPS may narrow, and even eliminate, this gap. Locating mobile rents in a taxadvantaged jurisdiction takes more than just a reallocation of "paper profits" for income tax purposes and often requires some measure of change in a business's operations (such as location of employees, ways of dealing with outside parties, etc.). For profits reported in a jurisdiction to be respected for income tax purposes, the international tax rules require that such reported profits be supported by sufficient "economic substance." 45 Absent the requisite economic substance, the company's cross-border allocation of taxable income is unlikely to be respected and the effective tax on such profits will not be lowered. ${ }^{46}$ In turn, economic substance - in the context of mobile rent-generating capital such as intangible property (IP) - effectively amounts to observable economic activity in the form of employees that are responsible for performing important functions that have a bearing on the profit-making potential of the relevant IP. To the extent that the United States is the "natural home" of such economic substance for a U.S. MNC in a world without tax considerations - for instance, on account of linkages and network economies with

${ }^{43}$ The incentives of jurisdictions offering lower tax rates to attract rents from mobile forms of capital have only been heightened with the OECD's BEPS project and the greater substance requirements for cross-border related-party allocations of intangible-related income to be respected. With a higher substance threshold, a government offering lower tax rates on intangible income not only stands to attract more taxable income but also more real economic activity, such as jobs.

See Kartikeya Singh \&Aparna Mathur BEPS and the Law of Unintended Consequences, TAX NOTES (TA) (Sept. 16, 2013).

\footnotetext{
${ }^{44}$ I.R.C $\$ 245 \mathrm{~A}$.

${ }^{45}$ OECD, supra note 26 , at 3.

${ }^{46} I d$. at $13,38$.
} 
other aspects of the company's business - locating the requisite economic substance in a low-tax jurisdiction will come at an incremental cost. Such incremental non-tax costs for the firm would be present to the extent it has to organize its business affairs (e.g., such as the location of its employees and their roles and responsibilities) differently from how it would do so in a no-tax world. Any such non-tax costs then represent a leakage from the tax benefit the firm may generate from its investment location choice.

The non-tax transaction costs related to international tax planning may be higher still on account of additional compliance and administrative burdens that a U.S. MNC might face when locating rent-generating capital outside of the United States for tax considerations. The additional compliance and administrative burdens can come from having to defend its location choice of IP - a choice that may have the appearance of having been made specifically for tax purposes - to revenue authorities of different jurisdictions that may have an interest in challenging the company's position in order to appropriate a greater share of tax revenues.

It is fair to say that the transaction costs related to international tax planning that a firm faces are higher in the post-BEPS world than before. From the outset of the BEPS project, the OECD had identified intangibles - as the quintessential form of mobile capital that can be moved across jurisdictions relatively easily - as a key area where new rules and a tightening of existing rules was needed to curb the ability of multinationals to "artificially" shift profits from high-tax to low-tax jurisdictions. ${ }^{47}$ Correspondingly, the OECD devoted a significant part of its new guidelines, presented in the report on BEPS Actions 8 through 10, to intangibles and the crossborder allocation of taxable income attributable to such intangibles. ${ }^{48}$ The new guidelines reinforced the concept of "economic substance" as a way to ensure that whenever a taxpayer asserts a jurisdiction as its location for important intangibles (and taxable income attributable to them), it has to show that it meets a necessary and elevated precondition: the location of employees necessary for the development, management, and exploitation of the intangibles within that same jurisdiction. ${ }^{49}$ This is intended to minimize (if not entirely eliminate) "artificial profit shifting" where the location of income attributed to a company's intangibles is disassociated from the location of important people functions ${ }^{50}$ In effect, the revised guidelines and standards impose a significant transaction cost on firms' international tax planning built around the location of intangible capital.

So, how do the new rules on FDII and GILTI impact the decision margins of U.S. MNCs with regard to new investments in an international tax environment shaped by BEPS? Commentary within the US has been mixed. Some commentators have argued that the provisions do not do enough to change the "offshoring problem" and recommend "equalizing the minimum tax rate on GILTI" and "the reduced rate on exports" to close the tax arbitrage window mentioned above, in particular citing a "tax haven problem". ${ }^{51}$ Others have noted that the new rules do indeed reduce (although, without completely eliminating) the incentive to offshore investments and also point to the potential effect of GILTI being far more punitive than

\footnotetext{
${ }^{47}$ OECD, supra note 25 , at 13.

${ }^{48}$ See OECD, supra note 26, at 63-92.

${ }^{49} \mathrm{Id}$. at $38-9$.

${ }^{50} \mathrm{OECD}$, supra note 25 , at 18.

${ }^{51}$ Kamin et al., supra note 7 , at 56.
} 
immediately apparent. ${ }^{52,53}$ We turn to an analysis of the effects of the GILTI and FDII provisions on U.S. MNCs' incentives with regard to the location of new investments. We explicitly incorporate into this analysis non-tax transaction costs that a firm may have to face when considering its location choice.

\section{FIRM'S LOCATION CHOICE FOR NEW INVESTMENTS WITH GILTI AND FDII ${ }^{54}$}

To consider the impact of the provisions, we compare the after-tax net present value (NPV) and the internal rate of return (IRR) of a new investment when it is located within the United States to when it is located in a low-tax foreign jurisdiction. For simplicity, we assume that the investment generates income entirely from foreign consumption or use.

We consider a new $\$ 10$ million investment in year 0. Assuming an economic life of five years and constant straight-line depreciation, the investment starts depreciating in year 1 and is fully depreciated by the end of year 5. ${ }^{55}$ Further, the undepreciated portion of the investment starts to generate returns in year 1 with each year's return being made up of two components: the normal return equal to 10 percent and economic rents at a rate of 20 percent. The total before-tax return is then 30 percent. The assumption of a high rate of economic rents is appropriate for the types of investment targeted by the GILTI and FDII rules. The pre-tax outlays, net capital stock and returns from the investment over its life cycle are shown in Table 1.

\section{Table 1: Before-Tax Outlays, Net Capital Stock and Returns}

(All figures in million USD)

\begin{tabular}{|c|c|c|c|c|c|c|c|}
\hline Year & $\begin{array}{c}\text { (A) } \\
\text { Investment } \\
\text { Outlay }\end{array}$ & $\begin{array}{c}\text { (B) } \\
\text { Net Capital } \\
\text { Stock }\end{array}$ & $\begin{array}{c}(\mathrm{C}) \\
\text { Economic } \\
\text { Depreciation }\end{array}$ & $\begin{array}{c}\text { (D) } \\
\text { Normal Return }\end{array}$ & $\begin{array}{c}(\mathrm{E}) \\
\text { Economic Rent }\end{array}$ & $\begin{array}{c}(\mathrm{F}) \\
\text { Total Gross } \\
\text { Return }\end{array}$ & $\begin{array}{c}(\mathrm{G}) \\
\text { Pre-Tax Cash } \\
\text { Flows from } \\
\text { Investment } \\
\end{array}$ \\
\hline 0 & $(10.00)$ & & - & - & - & - & $(10.00)$ \\
\hline 1 & 0.00 & 10.00 & 2.00 & 1.00 & 2.00 & 5.00 & 5.00 \\
\hline 2 & 0.00 & 8.00 & 2.00 & 0.80 & 1.60 & 4.40 & 4.40 \\
\hline 3 & 0.00 & 6.00 & 2.00 & 0.60 & 1.20 & 3.80 & 3.80 \\
\hline 4 & 0.00 & 4.00 & 2.00 & 0.40 & 0.80 & 3.20 & 3.20 \\
\hline 5 & 0.00 & 2.00 & 2.00 & 0.20 & 0.40 & 2.60 & 2.60 \\
\hline Total & & & 10.00 & 3.00 & 6.00 & 19.00 & 9.00 \\
\hline NPV & & & 7.58 & 2.42 & 4.84 & 14.84 & 4.84 \\
\hline
\end{tabular}

For now, we do not distinguish between investments in tangible and intangible capital, with each type analyzed separately below. Using Equation 4 and Equation 5, Table 2 shows the tax treatment of the investment in each year under expensing and depreciation.

${ }^{52}$ Martin A. Sullivan, Economic Analysis: Where Will the Factories Go? A Preliminary Assessment, 158 TAX NoTES 570 (Jan 29, 2018).

${ }^{53}$ Martin A. Sullivan, Economic Analysis: More GILTI than you thought, 89 TAX NOTES INT'L 587 (Feb. 12, 2018).

${ }^{54}$ The analysis in this section ignores U.S. state taxes as well as foreign tax credit limitations when computing the U.S. tax on GILTI.

${ }^{55}$ For simplicity, all cost outlays and income are assumed to occur at the beginning of the year. Additionally, the tax depreciation schedule, when relevant, is assumed to conform to true economic depreciation. 
Table 2: Taxable Income under Alternative Capital Allowance Regimes (All figures in million USD)

\begin{tabular}{|l|r|r}
\hline Year & $\begin{array}{c}(\mathrm{H}) \\
\text { Taxable Income } \\
\text { under } \\
\text { Immediate } \\
\text { Expensing }\end{array}$ & $\begin{array}{c}\text { (I) } \\
\text { Taxable Income } \\
\text { under } \\
\text { Depreciation } \\
\text { Deduction }\end{array}$ \\
\hline \hline 0 & $(10.00)$ & 0.00 \\
\hline 1 & 5.00 & 3.00 \\
\hline 2 & 4.40 & 2.40 \\
\hline 3 & 3.80 & 1.80 \\
\hline 4 & 3.20 & 1.20 \\
\hline 5 & 2.60 & 0.60 \\
\hline Total & 9.00 & 9.00 \\
\hline NPV & 4.84 & 7.26 \\
\hline
\end{tabular}

Under the assumptions made for this hypothetical investment, taxable income under immediate expensing is identical to the before-tax cash flows. In contrast, with deductibility of depreciation, taxable income is the sum of the normal return and the economic rents. Consistent with the discussion in Section II, the expensing regime only imposes a tax on the economic rents in present value terms ( $\$ 4.8$ million) whereas the depreciation regime taxes both the normal return and the economic rents ( $\$ 7.3$ million).

\section{A. The Imputed Return in the GILTI and FDII Rules}

Before we proceed with our analysis of investment location, we make a slight digression regarding the normal rate of return. The imputed return on depreciable tangible assets (i.e., QBAI) set forth in the TCJA in the application of the GILTI and FDII provisions is an important design feature of GILTI and FDII rules and one that has not escaped comment. Views on this range from the 10 percent figure having been "pulled out of thin air" and therefore lacking any basis to it being too high "compared to similar provisions in the code, which set returns a few percentage points above the risk free return." 56 We have a different view on this issue.

We conjecture that the imputed return on tangible assets chosen in the design of the GILTI and FDII provisions is a proxy for the normal rate of return attributable to tangible (and hence, relatively immobile) capital so as to isolate economic rents that accrue to more mobile capital. For equity-financed investments, the normal return is the required market rate of return on equity in the applicable risk class. ${ }^{57,58}$ Without knowing the specifics of the taxpayer and the investment in question, a reasonable guess for this normal rate of return is the expected return on equity in the overall economy. If one were to use the past to derive an expectation of the future,

${ }^{56}$ Sullivan, supra note 52. See also Kamin et al., supra note 7 at 46.

57 See Rachel Griffith et al., International Capital Taxation, in DIMENSIONS OF TAX DESIGN: THE MIRRLEES REVIEW 914, 926 (James Mirrlees et al., eds., 2010).

${ }^{58}$ For debt-financed investments, the normal return is the market rate of interest on debt (which is subtracted out of the "net deemed tangible income return" under the GILTI and FDII rules since, with the deductibility of interest expense, this portion is already exempt from tax). I.R.C §951A(b)(2)(B). 
10 percent is a close estimate of the average return on the S\&P $500 .{ }^{59}$ This may be the thinking underlying the GILTI and FDII rules. In fact, the House Ways and Means Committee's counterpart to the GILTI rules used a rate of seven percent plus a short-term federal interest rate. ${ }^{60}$ The seven percent figure is a close approximation of the excess of the average historical equity returns over the risk-free rate. ${ }^{61}$ The House and Ways and Means Committee proposal thus also appears to have used a similar imputed return in its equivalent to the GILTI provision as the historical annual return on equity for the S\&P 500 (albeit through a slightly different route).

The 10 percent imputed return in the GILTI and FDII provisions thus may not have been pulled out of thin air. That by itself fails to say whether it is in fact an appropriate figure to use as the imputed return in the provisions. To assess whether the 10 percent imputed return figure is appropriate in the context of its intended purpose -identifying the normal rate of return so as to exempt this (as hypothesized by us) under the GILTI provision - requires answering the following question: what discount rate would an (equity) investor use to present value the deductions from projected future taxable income that are available via the deemed tangible return income" (i.e., the imputed return on QBAI) under the provision ${ }^{62}$ In particular, should the hypothetical investor use a relatively safe rate of return or one that incorporates an equity risk premium? The discount rate that the investor uses is what should be used as the imputed return so as to ensure the desired tax neutrality (i.e., specifically identifying the economic rents so as to leave the normal returns untaxed on a present value basis). ${ }^{63}$

A relatively safe rate would be appropriate for the imputed return if the "deemed tangible return income" for a given year could be carried forward or back to offset the "tested income" amounts in other years so as to lower the GILTI amounts in those years. If this were the case, a U.S. MNC would almost be guaranteed the tax benefit of the imputed return. The only situation under which (an equity investor) in the U.S. MNC would stand to lose the benefit of the imputed return on QBAI would be where the relevant CFCs of the company never generate enough tested income for the investor to benefit from the imputed return on QBAI. The risk associated with such a situation is akin to that of bankruptcy (of the relevant CFCs). Thus, if the GILTI provision in the TCJA allowed a taxpayer to carry the "deemed tangible income return" forward to offset future GILTI liabilities, an investor would discount these future deductions at a rate equal to the risk-free rate plus a default risk premium. Taking administrative considerations into account, a rate equal to an average corporate borrowing rate would be reasonable proxy for the imputed

${ }^{59}$ See Michael Santoli, The S\&P 500 Has Already Met Its Average Return for a Full Year, But Don't Expect It to Stay Here, CNBC, (June 18, 2018), https://www.cnbc.com/2017/06/18/the-sp-500-has-already-met-itsaverage-return-for-a-full-year.html [https://perma.cc/8U6W-KR5Y].

${ }^{60}$ Section 4310, Tax Cuts and Jobs Act, Pub. L. No. 115-97, 131 Stat. 2054 (2017).

${ }^{61}$ Roger J. Grabowsi ET AL., 2017 VALUATION HANDBOOK - U.S. GuIDE TO Cost OF CAPITAL (2017).

${ }^{62}$ For the purposes of this discussion, we focus on the GILTI provisions, but the analogous reasoning applies to FDII provisions.

${ }^{63}$ The reasoning mirrors that used for purposes of determining the appropriate imputed return used in the allowance for corporate equity (ACE) rules adopted in certain countries. The exemption of the normal return from tax is an objective for ACE rules (in addition to reducing distortions in debt versus equity financing decisions).

See Griffith et al., supra note 57, at 977-78. 
return in the provision. This would not be too different from what some commentators have opined that the 10 percent imputed return is too high. ${ }^{64}$

However, the above applies only if the GILTI rules were to allow carryforward of "excess" deemed tangible return income amounts to shield tested income, and thereby reduce GILTI, in other years. This is not the case in the actual design of the GILTI provision. The GILTI amount is lower in any given year by the 10 percent imputed return on QBAI when the "tested income" for the U.S. MNC's CFCs exceeds this imputed amount. However, in the situation where the 10 percent imputed return exceeds the tested income amount, the GILTI amount subject to US tax for that year, other things equal, is zero. But the excess of the imputed return over the tested income does not carry forward to shield tested income amounts in future years nor can it be carried back. Instead the value of this deduction is limited to the specific year in question and is tied to the realization of the uncertain return in that year. ${ }^{65}$ This implies that the discount rate an investor would use to calculate the present value of the imputed income on the QBAI cannot be a safe rate of return since this deduction is not guaranteed. In turn, this means that the appropriate discount rate the equity investor should apply to calculate the present value of this deduction cannot be too far removed from the discount rate that would apply to calculate present value of the uncertain return. The expected rate of return on equity is therefore not far off from an appropriate candidate for this discount rate. Correspondingly, the same rate of return as the imputed return in the provision may not be too far off the mark. Certainly, a safe rate of return would not be an appropriate choice for this imputed return.

With this slight digression on the normal rate of return out of the way we now turn to the analysis of the location choice of our candidate investment described earlier in the section.

\section{B. Intangible Capital ${ }^{66}$}

For intangible capital, the tax treatment given by column $(\mathrm{H})$ in Table 2 is assumed to apply, regardless of the location of the investment. As discussed above, the tax codes of most jurisdictions, including the United States, currently allow immediate expensing of most investments in self-developed intangibles. ${ }^{67}$ Because the expensed investment has zero tax basis, the QBAI for purposes of GILTI and FDII is zero in each year.

If the U.S. MNC locates this investment in the United States, it would benefit from the FDII rules. Its total tax liability in years 0 through 5 is shown in Table 3.

${ }^{64}$ Kamin et al., supra note 7, at 46.

${ }^{6}$ See Prop. Treas. Reg. § 1.951A-(1)(c)(3)(i)1, 83 Fed. Reg. 51,072, 51,093 (Oct. 10, 2018) (defining "net deemed tangible income return" with respect to a "United States shareholder and a U.S. shareholder inclusion amount means with respect to a United States shareholder and a U.S. shareholder inclusion year, the excess (if any) of-(A) (t)he shareholder's deemed tangible income return ... for the year, over, (B) (t)he shareholder's specified interest expense ... for the year.") (emphasis added). See also Prop. Treas. Reg. § 1.951A-(1)(c)(3)(ii), 83 Fed. Reg. 51,072, 51,093 (Oct. 10, 2018) (defining "deemed tangible income return" with respect to a United States shareholder as " 10 percent of the aggregate of the shareholder's pro rata share of the qualified business asset investment ... of each tested income CFC for the year.") (emphasis added).

${ }^{66}$ For a comparison of the United States with other jurisdictions with regard to tax incentives for researchbased intangible investments, see Andrew Lyon \& William A. McBride, Assessing US Global Tax Competitiveness after Tax Reform (paper presented to Nat. Tax Ass'n 2018 Spring Symposium, Washington, DC, May 17, 2018).

${ }^{67}$ For the U.S., this will change for certain types of research and engineering expenses after 2022 when such expenses will have to be amortized for tax purposes over five years. I.R.C. $\$ 174$ modified with effect for tax years beginning after December 31, 2021 pursuant to I.R.C. $\$ 174(\mathrm{e})$ introduced in P.L. 115-97. 
THE IMPACT OF GILTI AND FDII ON THE INVESTMENT LOCATION CHOICE OF U.S. MULTINATIONALS

Table 3: Total Tax Liability when Locating Intangible Investment in the United States ${ }^{68}$ (All figures in million USD)

\begin{tabular}{|l|r|r|r|r}
\hline Year & \multicolumn{1}{|c|}{$\begin{array}{c}\text { (J) } \\
\text { Regular US Tax } \\
\text { Liability }\end{array}$} & \multicolumn{1}{c|}{ FDII } & $\begin{array}{c}\text { (L) } \\
\text { FDII Tax } \\
\text { Benefit }\end{array}$ & $\begin{array}{c}\text { (M) } \\
\text { US Tax Liability } \\
\text { with FDII } \\
\text { Benefit }\end{array}$ \\
\hline \hline 0 & $(2.10)$ & $(10.00)$ & 0.79 & $(1.31)$ \\
\hline 1 & 1.05 & 5.00 & $(0.39)$ & 0.66 \\
\hline 2 & 0.92 & 4.40 & $(0.35)$ & 0.58 \\
\hline 3 & 0.80 & 3.80 & $(0.30)$ & 0.50 \\
\hline 4 & 0.67 & 3.20 & $(0.25)$ & 0.42 \\
\hline 5 & 0.55 & 2.60 & $(0.20)$ & 0.34 \\
\hline Total & 1.89 & 9.00 & $(0.71)$ & 1.18 \\
\hline NPV & 1.02 & 4.84 & $(0.38)$ & 0.63 \\
\hline
\end{tabular}

In the table, column (J) represents the regular tax liability of the firm in the absence of FDII rules and is simply the taxable income shown in column $(\mathrm{H})$ of Table 2 multiplied by the U.S. tax rate of 21 percent. Column (K) shows the amount of income that is characterized as FDII. ${ }^{69}$ Because the investment only generates income derived from foreign use and has zero tax basis, the FDII corresponds to the taxable income in each year. Column (L) denotes the tax benefit of the FDII deduction, which equals 37.5 percent of each year's FDII multiplied by the 21 percent U.S. tax rate. Finally, column (M) shows the firm's total tax liability (inclusive of the tax benefit conferred by FDII) as the sum of columns (J) and (L). In this example, over the specific new investment's entire life cycle, the tax liability equals $\$ 0.6$ million in present value terms. Absent the FDII rules, and given expensing of the investment, the U.S. government would be a silent partner in the entire investment. This means that the normal rate of return from the investment would go untaxed (in present value terms) but all the economic rents would be taxed at the 21 percent rate. With the FDII rules, the U.S. government is a silent partner in only 62.5 percent of the investment. The normal rate of return still remains untaxed and, in addition, now 37.5 percent of the firm's economic rents are also exempted from U.S. tax. This is the impact of the FDII carrot.

Now, suppose that the MNC has the choice of locating this investment in a zero-tax foreign jurisdiction. Doing so will subject the firm to the GILTI rules. The firm's total tax liability in years 0 through 5 is shown in Table 4.

\section{Table 4: Total Tax Liability when Locating Intangible Investment Overseas}

${ }^{68}$ Negative FDII tax benefit figures imply a reduction in U.S. tax liability.

${ }^{69}$ The investment outlay in year 0 , and the immediate expensing of such investment for tax purposes, means that the deduction reduces the FDII generated from investments of older vintages. Said differently, as long as the firm has income from investments made in years prior to year zero (which is labeled as such specifically in relation to the current investment), and the FDII associated with such older investments would have been greater than $\$ 10$ million (but for the current investment), the marginal impact of the current investment on the firm's FDII in year 0 is $-\$ 10$ million. 
(All figures in million USD)

\begin{tabular}{|l|r|r|r|r}
\hline Year & $\begin{array}{c}\text { (N) } \\
\text { Foreign Tax }\end{array}$ & $\begin{array}{c}\text { G) } \\
\text { GILTI }\end{array}$ & $\begin{array}{c}\text { (P) } \\
\text { US Tax on } \\
\text { GLTI }\end{array}$ & $\begin{array}{c}\text { (Q) } \\
\text { Total Tax } \\
\text { Liability } \\
\text { Foreign plus } \\
\text { US) }\end{array}$ \\
\hline \hline 0 & - & $(10.00)$ & $(1.05)$ & $(1.05)$ \\
\hline 1 & - & 5.00 & 0.53 & 0.53 \\
\hline 2 & - & 4.40 & 0.46 & 0.46 \\
\hline 3 & - & 3.80 & 0.40 & 0.40 \\
\hline 4 & - & 3.20 & 0.34 & 0.34 \\
\hline 5 & - & 2.60 & 0.27 & 0.27 \\
\hline Total & - & 9.00 & 0.95 & 0.95 \\
\hline NPV & & 4.84 & 0.51 & 0.51 \\
\hline
\end{tabular}

Column $(\mathrm{N})$ lists the zero foreign tax liability. Column $(\mathrm{O})$ shows the amount of the taxable income classified as GILTI, which equals all the foreign pre-tax income because the investment has zero tax basis and does not give rise to QBAI. The negative taxable income under GILTI in year 0 assumes that this offsets GILTI income elsewhere at the level of the relevant U.S. corporate shareholder thereby allowing us to analyze the marginal impact of this investment location decision. ${ }^{70,71}$ Column (P) shows that the U.S. tax is 10.5 percent of the gross returns. The GILTI rules combined with the section 250 deduction that applies to a U.S. shareholder's GILTI income, positions the U.S. government as a silent partner in 50 percent of the firm's investment - the government effectively allows immediate expensing of 50 percent of the overseas investment and then taxes 50 percent of the gross returns. ${ }^{72}$ The firm's tax liability - all of which is on account of GILTI - is exactly half of what it would be if it located this investment in the United States and did not have the benefit of FDII. The tax liability is 80 percent of what the firm would pay if it located the investment in the United States and availed itself of the FDII benefit on account of the relative percentage of income subject to U.S. tax under the two cases (i.e., $50 \%$ versus $62.5 \%$ ).

Ignoring any non-tax costs for now, the firm's after-tax cash flows from the investment as well as the IRR and NPV of the investment corresponding to each location choice are shown in Table 5.

\section{Table 5: After-Tax Cash Flows, NPV and IRR from Intangible Investment (United States versus Overseas)}

${ }^{70}$ In the situation where this assumption is not met - not an entirely unrealistic possibility - the U.S. tax treatment of the investment would be worse than that of a silent partner. The resulting U.S. tax liability under the GILTI provision would correspondingly be significantly higher and would lead to an outcome worse than when it chooses the United States as the investment location.

${ }^{71}$ Note that the rules on GILTI as well as those on FDII correctly isolate the economic rents in this example (\$4.8 million in present value terms). The capital allowance rules (i.e., immediate expensing) in both jurisdictions, and the way QBAI is computed for the investment in question allow the provisions to achieve this policy objective.

${ }^{72}$ I.R.C. $\S 250(\mathrm{a})(1)(\mathrm{B})$. 
(All figures except percentages in million USD)

\begin{tabular}{|c|c|c|}
\hline Year & $\begin{array}{c}(\mathrm{R}) \\
\text { Investment } \\
\text { located in US }\end{array}$ & $\begin{array}{c}(\mathrm{S}) \\
\text { Investment } \\
\text { located } \\
\text { Overseas }\end{array}$ \\
\hline 0 & $(8.69)$ & $(8.95)$ \\
\hline 1 & 4.34 & 4.48 \\
\hline 2 & 3.82 & 3.94 \\
\hline 3 & 3.30 & 3.40 \\
\hline 4 & 2.78 & 2.86 \\
\hline 5 & 2.26 & 2.33 \\
\hline IRR & $30.00 \%$ & $30.00 \%$ \\
\hline NPV & 4.20 & 4.33 \\
\hline
\end{tabular}

The values for years 0 through 5 in column $(\mathrm{R})$ in the table represent the difference between before-tax cash flows from column $(\mathrm{G})$ in Table 1 and the total tax liability in column (M) from Table 3. Similarly, column (S) is the difference between column (G) in Table 1 and column (Q) in Table 4. The table shows that the firm's after-tax IRR remains the same regardless of its investment location decision. In each case the U.S. government acts as a silent partner in the investment and leaves the normal return untaxed. The percentage of investment in which the U.S. government "silently" participates is greater and as such, the upfront cost to firm is correspondingly lower when the investment is located in the United States (\$8.69 million versus $\$ 8.95$ million). The subsequent gross returns are taxed more heavily when the investment is located in the United States as well with the result that the investment's NPV is higher when it's located overseas.

The NPV analysis appears to confirm the view that the rules on FDII and GILTI do not adequately close the tax-arbitrage window for mobile capital. ${ }^{73}$ However, as discussed above, this may not represent a complete picture of the firm's decision criteria were it to incur incremental non-tax costs when choosing to locate its mobile capital (e.g., IP) in the foreign jurisdiction (especially when tax arbitrage is the primary motivation for such a decision). Such transaction costs may come from having to locate the requisite economic substance - with such requisite level being higher in the post-BEPS world - away from what would be its optimal location in a world without tax considerations. ${ }^{74}$ Additional compliance and administering efforts (in a world with greater transparency and access to information by taxing authorities) will likely further contribute to such transaction costs. For the candidate investment in our example, a present value of such transaction costs greater than $\$ 127$ thousand - the difference between the NPVs under the two alternative locations - over the life cycle of the investment is enough to tilt

\footnotetext{
${ }^{73}$ If the investment were subject to constant returns to scale, the firm could replicate the investment's overseas NPV in the United States. It could do this by investing an amount that is higher in before-tax terms but that costs the firm the same on an after-tax basis as when it locates the investment overseas (i.e., $\$ 8.95$ million).

${ }^{74}$ See discussion in Section III.D.
} 
the balance back in favor of the United States as the favored investment location. This cutoff value for transaction costs amounts to 1.3 percent of the initial investment outlay and 1.7 percent of the NPV of the pre-tax gross returns (i.e., $\$ 2.4$ million in the normal return plus $\$ 4.8$ million in economic rents). Having to spend $\$ 127$ thousand as a transaction cost when planning and locating an investment of $\$ 10$ million in a tax-advantaged jurisdiction (which otherwise would not be the natural home of that investment) is not far-fetched.

Since normal returns are left untaxed regardless of the location, the divergence in the after-tax NPV comes purely from the tax burden borne by the economic rents. Consequently, this divergence is greater (smaller) the higher (lower) the expected economic rents from the investment. Figure 1 shows the "indifference" threshold for transaction costs - expressed as a percentage of the pre-tax present value of gross returns - and how this threshold varies with the rate of economic rents given other assumptions on the investment profile. Given other parameters of our example, and allowing the rate of economic rents to vary between 0 percent and 50 percent, the curve in Figure 1 represent the level of transaction costs that make the U.S. MNC indifferent between the United States and the zero-tax foreign jurisdiction as its investment location.

\section{Figure 1: Indifference Curve for Investment Location - Non-Tax Transactions Costs versus Rate of Economic Rents}

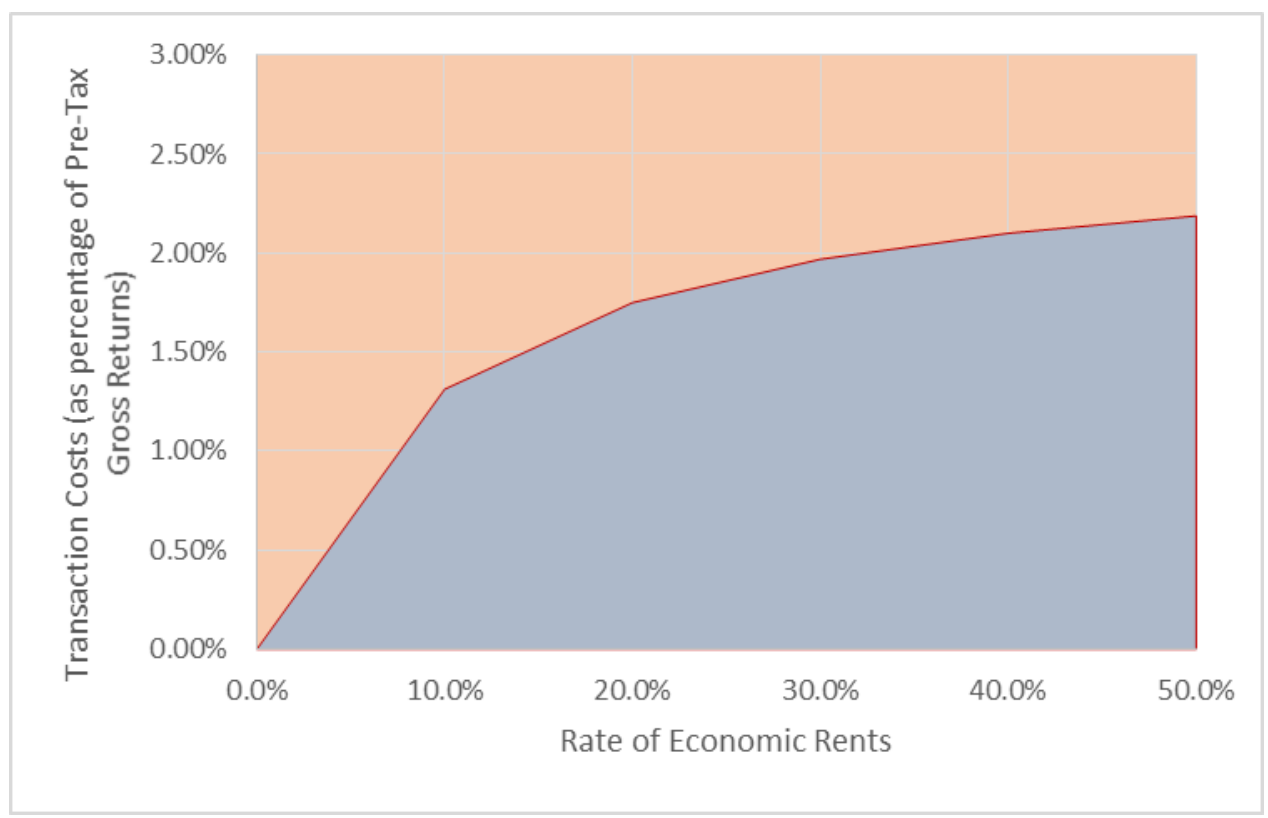

For any combination of transaction costs and economic rents lying above the "indifference curve" in Figure 1, the United States is the preferred location of the investment while the zerotax foreign jurisdiction is the preferred location for transaction cost-economic rent combinations that lie below the curve. The indifference curve itself shifts downwards - increasing the space over which the United States is the preferred investment location - as the foreign tax rate rises above zero. For a foreign tax rate equal to 13.125 percent, the indifference curve for the 
candidate investment in our example will coincide with the horizontal axis. ${ }^{75}$ Thus, for a range of investment profiles, the rules on GILTI and FDII might leave little or no tax-rate arbitrage opportunity when non-tax transactions costs over the investment's life cycle are fully incorporated in the firm's cost-benefit calculus. In particular, new investments with extremely (and possibly, implausibly) high rates of expected economic rents would be the suitable candidates for offshoring to low-tax jurisdictions. Other things equal, large scale investments might also be suitable candidates for offshoring. Non-tax transaction costs may exhibit some economies of scale and, in absolute terms, may be lower than the "indifference threshold" for extremely large investments with high expected rents.

\section{Tangible Capital}

Turning now to the location choice for new investments in tangible capital, the combination of the GILTI and FDII rules may provide a motivation for firms to locate tangible property overseas. ${ }^{76}$ First, 10 percent of QBAI (the tax basis in such tangible property) is removed from FDII, thereby lowering the tax benefit afforded by the FDII deduction. Second, and in the same vein, 10 percent of QBAI held overseas reduces GILTI and thereby reduces the tax's deterrent impact.

To analyze a U.S. MNC's location choice with regard to new investments in tangible capital we start with the same investment profile as shown in Table 1 but which is now assumed to apply to a tangible investment. The assumption of such high economic rents may seem implausible in the context of tangible capital. However, since the perceived benefit from offshoring tangible capital comes from such rents being shielded from U.S. tax by the 10 percent return on QBAI (as well as by enhancing the FDII benefit), the assumption of high rents to tangible capital allows us to evaluate the accuracy of that claim in the situation where it would be most likely to hold. ${ }^{77}$

Overseas jurisdictions that are likely candidate locations for tangible capital, such as factories, are unlikely to offer close to zero tax rates. Unlike the analysis above for intangible investments, the foreign tax rate assumed in this section is 8.5 percent. Our thinking behind this assumption is that the firm will be constrained to retain - for income tax purposes - at a minimum, the normal rate of return in the jurisdiction that houses the physical capital. We take the OECD average corporate tax rate of approximately 25 percent applying to this part of the income that will be reported in the candidate location of the tangible capital. ${ }^{78} \mathrm{We}$ assume an effective tax rate of zero on the economic rents as the best outcome the firm can effectively achieve by separating its location from that of the physical capital assuming it satisfies the types of post-BEPS considerations and constraints described in the previous section. ${ }^{79}$ The assumed

\footnotetext{
75 To reiterate, this ignores Section 904 limitations.

${ }^{76}$ Kamin et al., supra note 7.

${ }^{77}$ Readers may interpret the assumption as capturing the rate of economic rents in the overall system and not necessarily tied, or attributable to, the tangible system. The overall quantum of rents under such an interpretation bears a relationship to the scale of the tangible investment via the overall scale of operations.

${ }^{78}$ Corporate Tax Rates Around the World 2018, Daniel Bunn, Fiscal Fact 623, TAX FOUND., https://taxfoundation.org/corporate-tax-rates-around-world-2018/ [https://perma.cc/Z7BX-4L5E].

${ }^{79}$ See discussions in Section III.D.
} 
foreign tax rate of 8.5 percent on the total income generated from the investment when located overseas represents a rounded approximation of the weighted average tax rate on the normal return and the economic rents.

An important consideration with regard to investments in tangible capital is the expensing rules of section $168(\mathrm{k})$, as amended by section 13201 of the TJCA. For investments in certain forms of tangible capital made within the United States between 2018 and 2022, expensing means that the tax treatment of the investment is given by column $(\mathrm{H})$ in Table $2 .{ }^{80}$ In contrast, the tax rules of most jurisdictions allow only a depreciation deduction for investments in tangible capital. ${ }^{81}$ The tax treatment of the investment when located in a foreign jurisdiction is given by column (I) of Table 2. Note further, that the QBAI in each period, as determined under the section 168(g) alternative depreciation schedule, is assumed to correspond to the actual economic net capital stock shown in column (A) of Table 1.

Following the same order of analysis as before, if the firm locates this investment in the United States and benefits from the FDII rules, its total tax liability in years 0 through 5 is shown in Table 6 below.

Table 6: Total Tax Liability when Locating Tangible Investment in the United States (All figures in million USD)

\begin{tabular}{|l|r|r|r|r}
\hline Year & $\begin{array}{c}\text { (T) } \\
\text { Regular US Tax } \\
\text { Liability }\end{array}$ & \multicolumn{1}{c|}{ FDII } & $\begin{array}{c}\text { (V) } \\
\text { FDII Tax } \\
\text { Benefit }\end{array}$ & $\begin{array}{c}\text { (X) } \\
\text { US Tax Liability } \\
\text { with FDII } \\
\text { Benefit }\end{array}$ \\
\hline \hline 0 & $(2.10)$ & $(10.00)$ & 0.79 & $(1.31)$ \\
\hline 1 & 1.05 & 4.00 & $(0.32)$ & 0.74 \\
\hline 2 & 0.92 & 3.60 & $(0.28)$ & 0.64 \\
\hline 3 & 0.80 & 3.20 & $(0.25)$ & 0.55 \\
\hline 4 & 0.67 & 2.80 & $(0.22)$ & 0.45 \\
\hline 5 & 0.55 & 2.40 & $(0.19)$ & 0.36 \\
\hline Total & 1.89 & 6.00 & $(0.47)$ & 1.42 \\
\hline NPV & 1.02 & 2.42 & $(0.19)$ & 0.83 \\
\hline
\end{tabular}

The figures in Table 6 are derived in the same manner as those in Table 3. The difference between the tables starts with the amount of taxable income that constitutes FDII with the ensuing difference flowing through to the FDII benefit and total tax liability (inclusive of the FDII benefit). In Table 6, the FDII is lower in periods 1 through 5 by 10 percent of the QBAI (which is now positive in each of these periods under the ADS). Unlike the example of the intangible investment, the combination of expensing and the form of the investment generates QBAI means that the FDII rule does not accurately identify and isolate economic rents. The portion of the income that is identified as FDII ( $\$ 2.4$ million in present value terms) in the

${ }^{80}$ Our focus on an investment that qualifies entirely for the new expensing rules under the TCJA is admittedly a restrictive one. More realistic situations will have only a portion of an investment in a tangible asset e.g., a manufacturing plant - as qualifying for expensing.

${ }^{81}$ Pomerleau, supra note 29, at 2. 
example falls short of the full extent of the economic rents ( $\$ 4.8$ million) because of the subtraction of the normal return (\$2.4 million) ascribed to tangible capital from this pool of income. The 37.5 percent FDII deduction is only a mixed blessing in this case where expensing applies to investments in tangible capital. While the provision exempts 37.5 percent of the economic rents from U.S. tax, it puts 37.5 percent of the normal return back under the burden of the tax which otherwise would be exempt on account of the expensing provision. In our example, the net effect of the FDII deduction is still beneficial given the relative magnitude of the assumed rents. However, as these rents decline to zero, the firm would actually be better off not availing of the FDII provision so as to not dilute the benefit of expensing. ${ }^{82}$ We surmise that this may be an unintended design flaw in the provision and stems from a failure to correctly identify (in concept) the economic rents as the rightful target for the deduction.

When the firm instead locates the tangible investment in the foreign jurisdiction, and under the assumption that the local tax rules of the foreign jurisdiction do not allow for immediate expensing, taxable income is zero in the year the investment is made. Neither government does anything to defray the cost of the investment in year 0 . Given our assumed best case scenario for the firm, the foreign tax is limited to a weighted average rate of 8.5 percent in every subsequent year and the foreign tax liability is shown in column (Y) in Table $7 .^{83}$

The U.S. government imposes a tax on 50 percent of the taxable income in years from 1 through 5. However, because the taxable income in each year excludes depreciation (on account of the local capital allowance rules) as well as the normal return (via the 10 percent of QBAI exclusion), tax is imposed only on a portion of the economic rents. ${ }^{84}$ Therefore, even in the case of tangible investments, the GILTI rules result in the U.S. taxing no more than the economic rents, although that result is achieved via a different route than in the case of intangible investments. In this case, the U.S. also provides a credit for 80 percent of the firm's foreign tax liability. ${ }^{85}$ The end result is that the firm's U.S. tax liability under GILTI is lower both in present value and undiscounted terms than in the intangible investment case analyzed previously.

\footnotetext{
${ }^{82}$ Note that with lower rents, the firm's incentive to offshore the investment in pursuit of a lower tax rate also diminishes.

${ }^{83}$ Comparing the foreign tax liability in column (Y) from Table 7 with the regular U.S. liability in column (J) from Table 3 shows the benefit of expensing. The assumed foreign tax rate is only 40 percent of the U.S. tax rate yet yields a tax liability that is just over 60 percent of the regular U.S. tax liability (before the FDII benefit) in present value terms.

${ }^{84}$ The computation of the GILTI amount subject to U.S. tax starts with an after-tax amount (i.e., the "net CFC tested income") from which the imputed return on QBAI is deducted. The final GILTI amount subject to U.S. tax is a before-tax figure via the section 78 gross-up. The mechanics of this computation - especially the sequencing with regard to the subtraction of the imputed return on QBAI - mean that the non-zero foreign tax rates of the provision falls just short of isolating the full extent of the economic rents.

${ }^{85} \mathrm{We}$ assume that no limitations (e.g., from expense allocation) apply to the foreign tax credits. The allocation of expenses under the rules of I.R.C. $\$ 861$ can limit the foreign tax credit and thereby subject some foreign income to U.S. tax even when the CFCs foreign tax rate exceeds 13.125 percent. See Sullivan, supra note 53. In the context of this analysis, such limitations would increase the U.S. tax on GILTI and make the foreign jurisdiction less favorable, other things equal.
} 
Table 7: Total Tax Liability when Locating Tangible Investment Overseas $^{86}$ (All figures in million USD)

\begin{tabular}{|l|c|c|c|c}
\hline Year & $\begin{array}{c}\text { (Y) } \\
\text { Foreign Tax }\end{array}$ & GILTI & $\begin{array}{c}\text { (AA) } \\
\text { US Taxon } \\
\text { GILTI }\end{array}$ & $\begin{array}{c}\text { (AB) } \\
\text { Total Tax } \\
\text { Liability } \\
\text { (Foreign plus } \\
\text { US) }\end{array}$ \\
\hline \hline 0 & - & - & - & - \\
\hline 1 & 0.26 & 1.91 & 0.07 & 0.33 \\
\hline 2 & 0.20 & 1.53 & 0.06 & 0.26 \\
\hline 3 & 0.15 & 1.14 & 0.04 & 0.20 \\
\hline 4 & 0.10 & 0.76 & 0.03 & 0.13 \\
\hline 5 & 0.05 & 0.38 & 0.01 & 0.07 \\
\hline Total & 0.77 & 5.72 & 0.21 & 0.98 \\
\hline NPV & 0.62 & 4.61 & 0.17 & 0.79 \\
\hline
\end{tabular}

Analogous to the analysis for the intangible investment, the firm's after-tax cash flows from the tangible investment and the IRR and NPV of the investment are shown in Table 8.

Table 8: After-Tax Cash Flows, NPV and IRR from Tangible Investment (United States versus Overseas)

(All figures except percentages in million USD)

\begin{tabular}{|l|r|r}
\hline Year & \multicolumn{1}{c|}{$\begin{array}{c}\text { (AC) } \\
\text { Investment } \\
\text { located in US }\end{array}$} & $\begin{array}{c}\text { (AD) } \\
\text { Investment } \\
\text { located } \\
\text { Overseas }\end{array}$ \\
\hline \hline 0 & $(8.69)$ & $(10.00)$ \\
\hline 1 & 4.27 & 4.67 \\
\hline 2 & 3.76 & 4.14 \\
\hline 3 & 3.25 & 3.60 \\
\hline 4 & 2.75 & 3.07 \\
\hline 5 & 2.24 & 2.53 \\
\hline IRR & $29.1 \%$ & $26.7 \%$ \\
\hline NPV & 4.01 & 4.05 \\
\hline
\end{tabular}

The expensing and the FDII rules - each of them working only imperfectly with the investment characteristics assumed in our example - combine to provide a better expected after-tax IRR for the firm when it locates the tangible investment in the United States versus overseas in the hypothesized candidate foreign jurisdiction. The firm does marginally better from locating the investment overseas in terms of the after-tax NPV of the investment - even though the upfront after-tax outlay is higher, the subsequent returns face a lower tax burden. However, this benefit in terms of NPV is small - approximately $\$ 38$ thousand on a $\$ 10$ million investment and barely

${ }^{86}$ The amount shown in column $(\mathrm{Z})$ is after the section 78 gross-up (i.e., the amount subject to US tax under the GILTI provision). 
half a percent of the pre-tax NPV of gross returns. Furthermore, the benefit declines rapidly as the expected rate of economic rents in the system decline with the balance shifting in favor of the United States for low rates of rents. All of this suggests that the location of tangible capital is likely to be dictated much more by non-tax factors (such as cost/supply of labor, supply-chain considerations, etc.) and the new provisions, by themselves, are unlikely to significantly disadvantage the United States as a location for such investment.

\section{CONCLUSION}

The new GILTI and FDII rules have attracted widespread attention. In this paper, we analyze whether these rules help retain internationally mobile rents within the U.S. tax base and the associated economic activity within the United States. We compare investments with the same before-tax profiles in terms of their after-tax IRR and NPV when made in the United States versus when made abroad. Our analysis suggests that for a wide range of investment profiles (characterized in terms of size and expected above-normal returns) for intangible capital, a U.S. MNC can do better by locating the investment in the United States. When non-tax transaction costs are incorporated in the firm's cost-benefit calculus, the FDII rules provide a significant incentive for U.S. firms to locate new investments within the U.S. and the GILTI rules impose a significant-enough burden (by way of U.S. tax) such that a firm's NPV from an investment is greater when locating such an investment within the U.S. than in a low-tax foreign jurisdiction. Furthermore, our analysis also suggests that the rules, by themselves, do not dilute the above outcome by providing any significant incentive to locate new tangible capital outside of the United States. Our conclusions differ from other commentators' claim that the GILTI and FDII rules do not provide sufficient incentives for firms to locate investments within the US and even have the opposite effect for some investments. An important reason for the difference in our conclusions comes from our explicit consideration of non-tax transactions costs of tax planning in the post-BEPS global environment and our departure from a single-period perspective in favor of the entire life cycle of the investment.

Our analysis relies on a simplified and stylized framework and several caveats are applicable. We ignore state taxes in the interest of simplicity but also on account of the uncertainty around what path the states are likely to take with regard to the rules on GILTI and FDII. We note however, that incorporating U.S. state taxes in the analysis would likely increase a U.S. multinational's tax burden on its new investment in either location. By effectively assuming away foreign taxes in the case of intangible investments, we remove the issue of foreign tax credits that come into play with regard to the U.S. tax on GILTI. Relaxing this assumption is unlikely to alter the direction of our conclusions because it would make a foreign jurisdiction even less attractive relative to the United States. We ignore the impact of the new provision under section 59A on the base erosion and anti-abuse tax, which may make the overseas jurisdiction more unfavorable as an investment location choice. Finally, we ignore risk; as noted above, the government is a true silent partner only if it offers perfect loss offsets. Under the changes made to section 172 by section 13302 of the TJCA, the loss offset provisions for the U.S. are less generous than before and less generous than in many other jurisdictions. The loss 


\section{COLUMBIA JOURNAL OF TAX LAW}

offset restrictions are likely to erode some of the benefits of locating a new risky investment in the United States.

Despite the caveats, the analysis in this article suggests that when looking at the expected after-tax returns from a new investment over its entire life cycle and accounting for non-tax transactional costs, the threat of GILTI and the allure of FDII may combine to make the United States a more attractive location of rent-generating investment than might first appear. 